\title{
Farmer's Decision in Converting the Function of Agricultural Lands
}

\author{
Atika Fikri Tsani ${ }^{1)}$, Yunastiti Purwaningsih ${ }^{2)}$, Akhmad Daerobi ${ }^{\text {3) }}$ \\ 1) Faculty of Economic, Universitas Islam Batik \\ ${ }^{2,3)}$ Faculty of Economic and Business, Universitas Sebelas Maret \\ Corresponding Author: atikafikri47@gmail.com, yst_stm@yahoo.com, ad94784@gmail.com
}

Recieved: July 2017 | Revised: November 2017 | Accepted: November 2017

\begin{abstract}
This study aims to analyze the factors that affect farmer's decision in converting the function of their agricultural lands. The factors are: farmer's age, education level, total number of family members, the area of agricultural lands, income, and location of agricultural land. This study is conducted in Depok sub-district, Sleman district, Yogyakarta, as an area with high rate agricultural land function conversion, marked by the decrease in the area of agricultural land. This study is conducted using survey method, with farmers who decide to convert the function of their agricultural land and farmers who do not as unit analysis. The data is analyzed using logistic regression. The analysis result shows that farmer's age and agricultural land location have negative effect on the decision to convertagricultural land function, education level and total numbers of family members have positive effect, and the area of agricultural lands and income have no significant effect on the decision to convert the function of agricultural lands.
\end{abstract}

Keywords: conversion ofagricultural lands function, farmer's decision, logistic regression JEL Classification: Q12, Q15

How to Cite: Tsani, A., Purwaningsih, Y., \& Daerobi, A. (2018). Factors Affecting Farmer's Decision in Converting The Function of Agricultural Lands. Jurnal Ekonomi Pembangunan: Kajian Masalah Ekonomi dan Pembangunan, 19(1), 1-11. doi:https://doi.org/10.23917/jep.v19i1.4435

DOI: https://doi.org/10.23917/jep.v19i1.4435

\section{Introduction}

The increase in economic development leads to the increase in the need for lands for housing and industry, or another economic activity. However, the availability of lands is very limited, thus there is a conversion of function from productive agricultural lands near to the city. Due to its proximity to the city, this kind of area usually has good facilities and infrastructure. This condition attracts investors to build housing, trade and service building, or industrial building. This explanation also in line with the argument from Supriyadi (2004) (agriculture to industrial), and demography (rural to urban) which in turn encourage conversion of agricultural land to nonagricultural lands.

According (Isa, 2014) lands needed for nonagricultural activities such as housing, industrial area, trading area, and services is exceptionally expansive, and mostly will come from agricultural lands, including paddies field. This phenomenon takes place due to the location selected in near to sub-urban area. The location is formerly dominated by agricultural lands which lately have been converted into non-agricultural land. The conversions of land function in the sub-urban area mainly caused by the low price of lands and the availability of facilities and infrastructure. 
Besides, paddies field which trapped by residential area or industrial area makes farmers experience difficulties in the access to water, human resource, and other production facilities so that they were forced to convert the function of their lands or even sell their agricultural land.

The conversion of agricultural lands should receive special attention from government considering that agricultural land is the source of food for the people. With the number of Indonesia population that reaches 250 million people, the government has to provide foods through food production. One of constraints in providing foods through production is the availability of land that keeps declining sue to the pressure from population growth and competition in the utilization of land between food and non-food sector (Purwaningsih, 2008)

The conversion of agricultural land function take place almost in all Java island, Sleman district in Yogyakarta is no exception. It is well known that Sleman district is a fertile area which becomes one of the bases for productive agriculture compared to the other districts/ municipals in Yogyakarta. However, the rate of conversion in this district is quite high, marked by the decrease in the agricultural lands area. The data show that in 2010 the area of paddies fields area in Sleman district is $22.708 \mathrm{Ha}$, and it decreases to $21.907 \mathrm{Ha}$ in 2015 or decreased by $801 \mathrm{Ha}(3.53 \%)$ during 2010-2015 (BPS DIY, 2015). From geographical point of view, Sleman district located near to the city, this is one of the factors that cause conversion of agricultural lands. This district also has a strategic position that eases the access to the city center, economic center, and education center.

There are several sub-district in Sleman that directly adjacent to Yogyakarta, among others is Depok sub-district. This sub-district located adjacent to Yogyakarta causes a high rate of conversion of agricultural lands. In this subdistrict, in 2013 there is 749.68 Ha paddies field, reduced to $505 \mathrm{Ha}$ in 2014, or there is a decrease of $32.64 \%$ (BPS Kecamatan Depok, 2015). The area of Depok sub-district covers three villages, Catur Tunggal, Maguwoharjo, and Condong Catur. From these three areas, Maguwoharjo and Condong Catur have high rate of conversion. During 2013-2014, in Maguwoharjo paddies field has been reduced by $22.29 \%$ (from $418.23 \mathrm{Ha}$ in 2013 to $325 \mathrm{Ha}$ in 2014), while in Condong Catur paddies field is reduced by $61.45 \%$ (from 246.43 $\mathrm{Ha}$ in 2013 to $95 \mathrm{Ha}$ in 2014 (BPS Kecamatan Depok, 2015). Complete data on the areas of land based on its usage in each village in Depok sub-district from 2013 and 2014 are presented in Table 1.

Depok sub-district is located next to Yogyakarta municipality, this leads to the high rate of agricultural land conversion. This assumption is strengthened with the theory of land lease suggested by Von Thunen in location theory. According to the theory, the difference of location among agricultural lands determines the land lease. The agricultural land lease will be higher if it is located in the center of market and it will be lower if it is located far away from market. The ability to pay lease also depends on location. Economic activity that is nearer to market will have higher ability to pay lease (Tarigan, 2006).

Several research find that the conversion of function from agricultural lands to nonagricultural lands leads to the increase in the price of land, and this is one of the driving factors for farmers to convert the usage of their lands (Benu, et al., 2013; Ilianda and Kuspriyanto, 2013; Halim, Rahman, and Hassan,2013). While the other factors that affect the conversion of agricultural lands function are the area of the land (Kamilah, 2013; Quasem, 2011), farmer's income (Benu \& Kindangen, 2013; Ilianda \& Kuspriyanto, 2013; Quasem, 2011), location of land (Quasem, 2011; Suputra, Ambarwati, G.a.a, Tenaya, \& Narka, 2012), farmer education level (Kamilah, 2013; Quasem, 2011; Suputra et al., 2012), farmer's age and total number of family members (Kamilah, 2013). 
Avalaible online at http://journals.ums.ac.id, Permalink/DOI: 10.23917/jep.v19i1.4435

Jurnal Ekonomi Pembangunan: Kajian Masalah Ekonomi dan Pembangunan, 19 (1), 2018, 1-11

Table 1. Area of land based on usage for each village in Depok sub-district 20132014 (Ha)

\begin{tabular}{|c|c|c|c|}
\hline \multirow{2}{*}{ Village } & \multirow{2}{*}{ Usage } & \multicolumn{2}{|c|}{ Year } \\
\hline & & 2013 & 2014 \\
\hline \multirow{4}{*}{ Catur Tunggal } & Paddies field & $\begin{array}{c}85.02 \\
(7.70 \%)\end{array}$ & $\begin{array}{c}85.00 \\
(7.70 \%)\end{array}$ \\
\hline & Homes and settlement & $\begin{array}{c}678.40 \\
(61.45 \%)\end{array}$ & $\begin{array}{c}678.42 \\
(61.45 \%)\end{array}$ \\
\hline & Dry land & $\begin{array}{c}43.04 \\
(3.90 \%)\end{array}$ & $\begin{array}{c}43.04 \\
(3.90 \%)\end{array}$ \\
\hline & Others & $\begin{array}{c}297.54 \\
(26.95 \%)\end{array}$ & $\begin{array}{c}297.54 \\
(26.95 \%)\end{array}$ \\
\hline \multirow{4}{*}{ Maguwoharjo } & Paddies field & $\begin{array}{c}418.23 \\
(27.86 \%)\end{array}$ & $\begin{array}{c}325.00 \\
(21.65 \%)\end{array}$ \\
\hline & Homes and settlement & $\begin{array}{c}452.42 \\
(30.14 \%)\end{array}$ & $\begin{array}{c}545.65 \\
(36.35 \%)\end{array}$ \\
\hline & Dry land & $\begin{array}{c}78.31 \\
(5.22 \%)\end{array}$ & $\begin{array}{c}78.32 \\
(5.22 \%)\end{array}$ \\
\hline & Others & $\begin{array}{c}52.04 \\
(36.78 \%)\end{array}$ & $\begin{array}{c}52.05 \\
(36.78 \%)\end{array}$ \\
\hline \multirow{4}{*}{ Condongcatur } & Paddies field & $\begin{array}{c}246.43 \\
(25.94 \%)\end{array}$ & $\begin{array}{c}95.00 \\
(10.00 \%)\end{array}$ \\
\hline & Homes and settlement & $\begin{array}{c}593.63 \\
(62.49 \%)\end{array}$ & $\begin{array}{c}45.06 \\
(78.43 \%)\end{array}$ \\
\hline & Dry land & $\begin{array}{c}8.31 \\
(0.87 \%)\end{array}$ & $\begin{array}{c}8.31 \\
(0.87 \%)\end{array}$ \\
\hline & Others & $\begin{array}{c}101.63 \\
(10.70 \%)\end{array}$ & $\begin{array}{c}101.64 \\
(10.70 \%)\end{array}$ \\
\hline
\end{tabular}

Source: Depok sub-district in numbers 2015

Ilianda \& Kuspriyanto (2013) Study the relationship between agricultural lands and income level, spending, and type of livelihoods in Paciran sub-district, Lamongan district. They conclude that the conversion of agricultural lands into nonagricultural lands in 2006-2010 occurs due to the high selling price of agricultural lands that will be used for industrial purposes. This condition causes many farmers who own agricultural lands to sell their lands to be converted into industrial lands. The impact of conversion of agricultural lands into non-agricultural use is an increase in income, spending, and types of livelihoods who shifted from farmers to other jobs. The changes in livelihoods, spending level, and income also changing depends on the current livelihood.
Benu \& Kindangen (2013) study the factors that affect conversion of land function in Tomohon, conclude that the factors that affect land conversion from economic aspect are farmers income level, economic activities, and price of lands. The factors that affect lands conversion from food safety aspect is the diversity of foods, the level of lands productivity, and fertility. Halim, Rahman, \& Hassan (2013) conduct a study on conversion of land function in metropolitan city Rajshahi, Bangladesh, conclude that the variables that have positive effect on the rate of conversion are population growth, infrastructure, business profit, price, and business cost. While the variables that have negative effect on the rate of conversion are civil facility, institution, and tax. 
Kamilah (2013) conducts a study on economic analysis of agricultural lands conversion in Bekasi (Case of Bekasi Utara sub-district and Bantar Gebang). The result shows that farmer's age, the area of lands before conversion, income before conversion, lands productivity, and farming experience, have positive effect on agricultural lands conversion. While education level and total number of family members have negative effect on agricultural lands conversion.

Suputra, Ambarwati,Tenaya, \& Narka (2012) analyze the factors that affect land conversion in Subak Daksina, Tibubeneng village, Kuta Utara sub-district, Badung district. The result of their study shows that there are four factors that affect land conversion, the condition of lands, the eviction factor (related with the condition of population), the factor of lands utilization (for private use), and the factor of the ineffectiveness of lands. The condition of land is measured using the income generated, the function of the lands, dry land, location of the land, proximity with city center, and wetlands. The factor of eviction is assessed from cramped settlements and population growth. The factor of land utilization is represented by the selling price of lands, production cost, and the need for housing for families. The factor of ineffectiveness of lands is represented by condition of roads, irrigation channel, and the opportunity to work in another field.
Quasem (2011) in a study regarding agricultural land conversion in Bangladesh conclude that the area of land, the area of residential land, occupation, and natural disaster affect the conversion of agricultural lands. The area of non-agricultural lands, education level, annual income, total assets, and location do not affect the conversion of agricultural lands.

This study analyzes the factors that affect farmer's decision in converting the function of their agricultural lands in Depok sub-district, Sleman district, Yogyakarta. The factors are farmer's age, education level, total number of family member, area of land, income, and location of land.

\section{Method}

This study uses primary data collected through survey method with the unit of analysis of both farmers who convert their agricultural lands function and who do not. The data are collected from Depok sub-district, Sleman district, Yogyakarta, with two villages, Maguwoharjo and Condong Catur, selected as samples. These villages are selected due to the high rate of conversion of agricultural lands. There are 70 farmers from two villages selected as research samples, 40 from farmers who convert the function of their agricultural lands, and 25 who do not. The data are analyzed using logistic regression (formula 1 ).

$$
\mathrm{h} \frac{\boldsymbol{P}}{1-P}=\mathrm{Y}=\beta_{0}+B_{1} \mathrm{X}_{1}+B_{2} \mathrm{D}_{2}+\mathrm{B}_{3} \mathrm{X}_{2}+\mathrm{B}_{4} \mathrm{X}_{3}+\mathrm{B}_{5} \mathrm{X}_{4}+\mathrm{B}_{6} \mathrm{D}_{2}+\mathrm{e}(1)
$$

Notes:

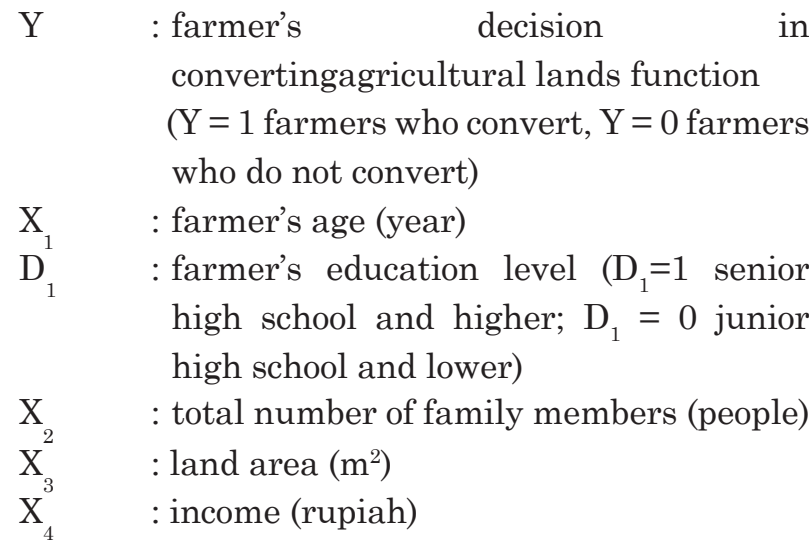

$\mathrm{D}_{2} \quad$ : location $\left(\mathrm{D}_{2}=1\right.$ far from city center; $\mathrm{D}_{2}=$ 0 near to city center)

$B_{0} \quad$ : constant

$B_{1}, \ldots, B_{6}:$ regression coefficient

e $\quad$ : error

\section{Result and Discussion}

\subsection{Characteristic of respondents}

The total number of famers based on gender and whether they perform conversion for their agricultural land are dominated by male farmers (Table 2).

Jurnal Ekonomi Pembangunan, ISSN 1411-6081, E-ISSN 2460-9331 
Table 2. Number of Farmers Based on Gender and Conversion of Agricultural Land Function

\begin{tabular}{lcccc}
\hline \multirow{2}{*}{ Gender } & \multicolumn{2}{c}{ Convert } & \multicolumn{2}{c}{ Do Not Convert } \\
\cline { 2 - 5 } & People & \% & People & \% \\
\hline Male & 29 & 64.44 & 18 & 72.00 \\
Female & 16 & 35.56 & 7 & 28.00 \\
\hline Total & 45 & 100.00 & 25 & 100.00 \\
\hline \multicolumn{3}{r}{} \\
\end{tabular}

Table 3. Number of Farmers According to Education Level and Converting Agricultural Land Function

\begin{tabular}{lcccc}
\hline \multirow{2}{*}{ Education level } & \multicolumn{2}{c}{ Convert } & \multicolumn{2}{c}{ Do Not Convert } \\
\cline { 2 - 5 } & People & \% & People & \% \\
\hline Elementary school & 12 & 26.67 & 23 & 92.00 \\
Junior high school & 27 & 60.00 & 2 & 8.00 \\
Senior high school & 6 & 13.33 & 0 & 0.00 \\
\hline Total & 45 & 100.00 & 25 & 100.00 \\
\hline \multicolumn{5}{c}{ Source: processed primary data, 2016 }
\end{tabular}

Table 4. Number of Farmers According to The Location and Converting Agricultural Land Function

\begin{tabular}{lcccc}
\hline \multirow{2}{*}{$\begin{array}{c}\text { Location According to The City } \\
\text { Center }\end{array}$} & \multicolumn{2}{c}{ Convert } & \multicolumn{2}{c}{ Do Not Convert } \\
\cline { 2 - 5 } & People & \% & People & \% \\
\hline Near & 40 & 89.89 & 19 & 76.00 \\
Far & 5 & 11.11 & 6 & 24.00 \\
\hline Total & 45 & 100.00 & 25 & 100.00 \\
\hline \multicolumn{4}{c}{ Source: processed primary data, 2016. }
\end{tabular}

Table 5. Respondent's Characteristic According to The Conversion of Agricultural Land Function

\begin{tabular}{lccc}
\hline \multicolumn{1}{c}{ Explanation } & Convert & $\begin{array}{c}\text { Do Not } \\
\text { Convert }\end{array}$ & $\begin{array}{c}\text { Result of t-test and } \\
\text { Significance Level }\end{array}$ \\
\hline Age (years) & 55 & 60 & $-5.5141^{* * * *}$ \\
Total number of family members (people) & 3 & 2 & $5.5021^{* * *}$ \\
Area of agricultural lands $\left(\mathrm{m}^{2}\right)$ & 1.747 & 1.332 & $0.7568^{\mathrm{ns}}$ \\
Income (Rp/month) & 3.588 .888 & 3.342 .000 & $0.8865^{\mathrm{ns}}$ \\
\hline \multicolumn{4}{c}{ Notes: ${ }^{* * *}$ significant at 1\%; ${ }^{\text {ns }}$ not significant. } \\
& Source: processed primary data, 2016.
\end{tabular}

According to farmer's education level, most of the farmers who perform conversion are junior high school graduates $(60.00 \%)$, while most of farmers who do not convert are elementary school graduates (92.00\%). The data shows that the higher the level of farmer's education, the higher the tendency for farmer to convert the function of their agricultural lands. This might be caused by the fact that farmers with higher education level have higher opportunity to work in nonagricultural field, which is considered as more profitable. However, with low education level the access to non-agricultural sector become limited. Complete data on a total number of farmers based on the level of education is presented in Table 3.

According to the location of agricultural lands, most of farmers, both they who convert and they who do not, are near to the city center (Table 4).

Respondent's characteristics according to the conversion of agricultural lands function that consist of mean value of farmer's age, number of family members, area of agricultural lands, and income, are presented in Table 5. 
Table 5 presents the mean value of farmer's age who converts is 55 years old, while the mean value of farmer's who do not converts is 60 years old. The oldest farmer who converts is 65 years old and the youngest is 44 years old. However, the oldest farmer who does not convert is 68 years old and the youngest is 56 years old. Based on the result of test of variance shows significant difference between the age of farmers in the category with significance level of $1 \%$, thus we can say that farmers who do not converts are generally older than farmers to convert the function of their agricultural land. The mean value of farmer's age who does not convert the function of their agricultural land is higher (older farmer) than the farmer's who convert the function of their agricultural lands because older farmers have less opportunity to work in nonagricultural sector, so they tend to preserve their agricultural lands as livelihoods. While younger farmers are considered as productive, so they have wider opportunity to work in non-agricultural sector once they convert the function of their agricultural lands.

The average number of family members from farmers who convert is three people, larger than family member of farmers who do not convert the function of their agricultural lands with only 2 people in a family, significant at $1 \%$ level (Table 5). On average, farmers who convert the function of their agricultural lands have larger number of families compared to farmer who does not convert the function of their agricultural lands. This finding is in line with the study conducted by Pewista \& Harini (2013) on the conversion of agricultural lands in Bantul district, Yogyakarta, with urban area, suburban area, and rural area during 20012010. The study shows that people with a large number of family members dominate the number of farmers who convert the function of their agricultural lands. This condition can be viewed as an effort from farmers to fulfill their household needs (with a large number of family members) with the income they get from converting the function of their agricultural lands. The phenomenon in which farmers with larger family members convert the function of their agricultural lands can be considered as an indication that agricultural lands are inherited assets, thus the larger the number of family members the higher the probability that the agricultural lands will be sold and the money from the selling to be divided among family members (inherited to their children).

The average area of farmer's agricultural lands that experience conversion is $1.747 \mathrm{~m} 2$ and 1.332 $\mathrm{m} 2$ agricultural lands do not change into settlement area (Table 5). However, statistically, there is no difference between the average area of agricultural lands between this two criteria. Similarly, farmer's income also has no difference between both types of respondent. The average income of the farmers over the function of $\mathrm{Rp} 3,588,888$ per month and the average income of farmers who are not over the function of $\mathrm{Rp} 3,342,000$ per month (Table 5 ). The absence of difference in the mean value of agricultural lands area and income based on the conversion of agricultural lands shows that the area of agricultural lands and income are not the factors that encourage farmers to convert the function of their agricultural lands. From previous researches, we find that the selling price is a factor that encourages the conversion of agricultural lands (Benu \& Kindangen, 2013; Halim et al., 2013; Ilianda \& Kuspriyanto, 2013; Pewista \& Harini, 2013).

All of the respondents are farmer, although for they who have convert the function of their agricultural lands they work as farm workers, tenant, or cultivators. This condition indicates that even after the conversion of agricultural lands takes place, productive agricultural lands are still available in the studied location. Another probability is that farmers only convert a part of their lands but still have some parts to plant. This finding is in line with the study conducted by Purwaningsih \& Istiqomah (2015) regarding the conversion of agricultural lands in Colomadu sub-district, Karanganyar district, Central Java province, that farmers who convert the function of their agricultural lands still work as farmer (farm worker, lessee, or cultivator). 
Avalaible online at http://journals.ums.ac.id, Permalink/DOI: 10.23917/jep.v19i1.4435

Jurnal Ekonomi Pembangunan: Kajian Masalah Ekonomi dan Pembangunan, 19 (1), 2018, 1-11

Table 6. Number of Farmers According To Side Job and The Conversion of Agricultural Land Function

\begin{tabular}{lcccc}
\hline \multirow{2}{*}{ Type of job } & \multicolumn{2}{c}{ Convert } & \multicolumn{2}{c}{ Do Not Convert } \\
\cline { 2 - 5 } & People & $\%$ & People & 33.33 \\
\hline Merchants & 12 & 60.00 & 3 & 0.00 \\
House maid & 2 & 10.00 & 0 & 55.56 \\
Construction workers & 2 & 10.00 & 5 & 0.00 \\
Retire & 1 & 10.00 & 0 & 0.00 \\
Security officer & 1 & 5.00 & 0 & 11.11 \\
Parking attendant & 1 & 5.00 & 1 & 0.00 \\
Motorbike taxi & 1 & 5.00 & 0 & 100.00 \\
\hline Total respondents & \multicolumn{2}{c}{20} & 100.00 & 9 \\
\hline
\end{tabular}

Table 7. Result of Regression Analysis on the Factors that affect Farmer's Decision to Convert the Function of Agricultural Lands

\begin{tabular}{lccccc}
\hline \multicolumn{1}{c}{ Variable } & $\begin{array}{c}\text { Coefficient of } \\
\text { regression }\end{array}$ & $\begin{array}{c}\text { Standard } \\
\text { Error }\end{array}$ & Wald & Significance & $\begin{array}{c}\text { Odds } \\
\text { Ratio }\end{array}$ \\
\hline Age $\left(\mathrm{X}_{1}\right)$ & -0.3723 & 0.1787 & 4.3418 & 0.0372 & 0.6891 \\
Education level( $\mathrm{D}_{1)}$ & 5.5918 & 2.9149 & 3.6802 & 0.0551 & 268.2192 \\
Number of family & 1.2005 & 0.6369 & 3.5533 & 0.0594 & 3.3217 \\
members $\left(\mathrm{X}_{2}\right)$ & & & & \\
Area of agricultural & 0.0001 & 0.0004 & 0.1698 & 0.6803 & 1.0001 \\
lands $\left(\mathrm{X}_{3}\right)$ & 0.0000004 & 0.0000007 & 0.4012 & 0.5265 & 1.0000 \\
Income $\left(\mathrm{X}_{4}\right)$ & -6.8139 & 3.1020 & 4.8250 & 0.0280 & 0.0011 \\
Location $\left(\mathrm{D}_{2}\right)$ & 21.9870 & 11.1040 & 3.9208 & 0.0477 & 3538687840.51079 \\
Constant & 0.8822 & & & \\
NagelrekeR-Square & 19.2222 & & & \\
LikelihoodRatioTest & & & & \\
(LR test) & 0.0000 & Source: processed primary data, 2016. & & \\
Probabilitas (LR test) & & & & \\
\hline
\end{tabular}

From all farmers who convert the function of their agricultural lands, 20 farmers or $44.44 \%$ have side job, while in farmers who do not convert the function of their agricultural lands, only nine people of $36 \%$ who have side job. We can state that farmers who have side jobs have higher opportunity to convert the function of their agricultural lands. The complete information regarding this data is presented in Table 6 .

Data in Table 6 shows that most of farmers who perform conversion of agricultural land function have side job as merchant $(60.00 \%)$, while most of farmers who do not convert the function of their agricultural lands have side job as construction worker (55.56\%).

\subsection{Factors Affecting Farmer's Decision in Converting The Function of Agricultural Lands}

The result of logistic regression analysis on the factors that affect farmer's decision to convert their agricultural lands function is presented in Table 7. The result of logistic regression analysis shows that farmer's age, total number of family members, and location of lands significantly affect farmer's in deciding to convert the function 
of their agricultural lands, while the area of lands and income has no significant effect on farmer's decision.Farmer's age and location of land have negative effect, education level and numbers of family members have positive effect on farmer's decision to convert the function of their agricultural lands.

The finding shows that farmer's age negatively and significantly affects farmer's decision in converting the function of their agricultural lands. This finding is strengthened by the data that shows the difference in mean value of farmer's age based on the conversion of agricultural lands, that in average, farmers who perform agricultural lands function conversion is younger than they who do not (Table 5). This result is in line with the research conducted by Kamilah (2013) which find that farmer's age has significant effect on the conversion of agricultural land function. The negative effect of farmer's age on the decision to convert the function of agricultural lands means that the older the farmer the lower the probability that the farmer will convert the function of their agricultural lands. When farmer gets older, farmer will retain their agricultural lands because they rely on agricultural activities. While for younger farmer, who are relatively still productive, they tend to find side jobs to fulfill their daily needs. The coefficient of regression for farmer's age is -0.3723 and the result of odd ratio computation is 0.6891 which means that the increase in farmer's age by a year will decrease the probability of converting the function of agricultural land by 0.6891 . The negative effect of age has an implication that young farmers would be interested to convert the function of their agricultural lands. Thus, government is expected to always give socialization and assistance to the young generation on the importance of sustaining agricultural lands. The government must have a trick so that young generation in the village area will be interested to work as a farmer.

Education level has a positive and significant effect on farmer's decision in converting the function of their agricultural land. Farmers who graduated from senior high school and higher education level have higher tendency to convert the function of their agricultural lands compared to farmers who graduated from junior high school. This is based on the assumption that the higher the level of education means that someone has an opportunity to work in the other sector besides agriculture, thus they tend to convert the function of their agricultural lands. This finding is in line with the finding from Kamilah (2013) who find that farmer's education has positive relationship with the activity of agricultural land conversion. The level of farmer's education has coefficient of regression of 5.5918 with odds ratio of 268.2192. This means that farmer's graduated from senior high school or higher level of education has an opportunity of 268.2192 higher that farmers graduated from junior high school, considering all the other factors are constant. Government and educational institution are expected to provide guidance and motivation for young generation on the importance of agriculture sector because agriculture has the biggest contribution toward gross domestic product (GDP), thus it is expected that prospective scientist will maintain agriculture sector in this agrarian country. Farmers also expected to provide and share knowledge regarding their paddies field to their children and or other younger family member, through this way, farmers will have a successor in managing their paddies field.

The total number of family member has a positive and significant effect on farmer's decision to convert the function of their agricultural lands. This means that the larger the number of family members, the higher the opportunity that farmer will convert their agricultural lands. This finding is supported with the data that shows the difference among the number of family based on the conversion of agricultural lands, in average the total number of members in family of farmer who convert the function of their agricultural lands is larger than they who do not convert the function of their agricultural lands (Table 5). Further, this finding is in line with the study 
conducted by Pewista \& Harini (2013) that people who convert the function of their agricultural lands are they who have larger family members. When farmer has higher responsibility, their needs will increase, thus they will sell their agricultural lands to fulfill their daily needs. This finding also indicates that the larger the number of family members means selling agricultural lands become highly probable due to inheritance factor. The number of family members has coefficient of regression of 1.2005 and odds ratio of 3.901. This means that the increase in the number of family member by one person will add the tendency of farmer to convert the function of their agricultural lands by3.901 times, with the assumption that all other variables constant. In this matter government is expected to give attention toward farmer's welfare by providing real and material aid so that farmers will be able to maintain and sustain as well as having 'eman' or devotion to their agricultural lands.

The area of lands and farmer's income has no effect on farmer's decision to convert the function of their agricultural lands. This finding contrasting the finding of study conducted by Quasem (2011), which find that the area of lands significantly affects land conversion. The finding of this research also contrasting the finding from Benu \& Kindangen (2013) which states that the factor that affects conversion of agricultural lands function from economic aspect is farmer's income level.

The location of agricultural lands has a significant and negative effect on farmer's decision to convert the function of their agricultural lands. Agricultural lands that are far away from the city center have lower chance to be converted by farmers compared to the lands that are near to the city center. The further the lands from the city center, the lower are the opportunity to convert the function of the land. Considering that agricultural land near to city center will have higher price, farmers tend to convert the function of their agricultural land. This finding is in line with the study conducted by Suputra et al (2012), and Pewista \& Harini (2013) which find that the location of agricultural lands affects the conversion of agricultural lands function. A strategic location of agricultural lands becomes a charm that attracts people to convert it into non-agricultural function, which is why land conversion is hard to be avoided. To avoid the conversion of agricultural lands which continues, the government needs to conduct a review of the spatial and territory planning regulation to reduce the activity of agricultural land conversion in Condong Catur and Maguwoharjo. The location of lands has coefficient of regression of -6.8139 and odds ratio of 0.0011 . This means that lands located far away from city center have the opportunity of 0.0011 times lower than the lands located near to the city center to be converted, considering all the other factors are constant.

\section{Conclusion}

Study regarding the conversion of agricultural lands is still needed and still relevant to be studied and demand attention from the government. Today topics in this field are focused on the high rate of conversion, especially productive agricultural lands that are converted into residential area, industrial area, and public infrastructure such as the development of toll highway. This study reveals the factors that affect farmer's decision to convert the function of their agricultural lands. The result of this study shows that farmer's age and location of agricultural lands have a negative effect, while education level and the number of family members have positive effect on the decision taken by farmers to convert the function of their agricultural lands. The older the farmers lower is the probability of converting the function of their agricultural lands. Thus, the government must develop a trick to attract young generation attention toward agriculture, considering they are in the productive age. Similarly the location of lands, the further away its location from city center, the lower is the opportunity that farmers will convert the function of the agricultural lands. 


\section{Acknowledgement}

In this part, we would like to thank the parties who have provided assistance in this study so that it can be presented in written publication, and published in Jurnal Ekonomi Pembangunan. We also offer our gratitude for the respondents, farmers in Condongcatur village and Maguwoharjo village who have provided their valuable time to supply us with information needed in this study.

\section{Reference}

Benu, N. M., \& Kindangen, P. (2013). Analysis of Land Conversion and its Impacts and Strategies in Managing Them in City of Tomohon, Indonesia. Asian Transactions on Basic and Applied Sciences, 3(2), 65-72.

BPS DIY. (2015). Daerah Istimewa Yogyakarta dalam Angka 2015. BPS Daerah Istimewa Yogyakarta, 625. https://doi.org/10.1017/ CBO9781107415324.004

BPS Kecamatan Depok. (2015). Kecamatan depok dalam angka 2014. In bps (Ed.) (2015th ed., p. 89). Sleman: BPS KECAMATAN DEPOK.

Halim, A., Rahman, M. M., \& Hassan, M. Z. (2013). Agricultural Land Conversion In The Sub-Urban Area: A Case Study Of Rajshahi Metropolitan City. Journal Life Earth Science, 8, 21-30.

Ilianda, T., \& Kuspriyanto. (2013). STUDI TENTANG ALIH FUNGSI LAHAN PERTANIAN TERHADAP TINGKAT PENDAPATAN, PENGELUARAN DAN JENIS MATA PENCAHARIAN MASYARAKAT DI KECAMATAN PACIRAN KABUPATEN LAMONGAN. Swara Bumi, 2(1), 125-132. Retrieved from http://jurnalmahasiswa.unesa.ac.id/index. php/swara-bhumi/article/view/856/1494

Isa, I. (2014). Strategi Pegendalian Alihfungsi Lahan Pertanian. Badan Pertanahan Nasional. Jakarta. Retrieved from http:// balittanah.litbang.pertanian.go.id
Kamilah, A. (2013). ANALISIS EKONOMI ALIH FUNGSI LAHAN PERTANIAN DI KOTA BEKASI (KASUS KECAMATAN BEKASI UTARA DAN BANTAR GEBANG). Jurnal Agribisnis Dan Pengembangan Wilayah, 5(1), 36-49.

Pewista, I., \& Harini, R. (2013). FAKTOR DAN PENGARUH ALIH FUNGSI LAHAN PERTANIAN TERHADAP KONDISI SOSIAL EKONOMI PENDUDUK DI KABUPATEN BANTUL. KASUS DAERAH PERKOTAAN, PINGGIRAN DAN PEDESAAN TAHUN 2001-2010. Jurnal Bumi Indonesia, 2(2), 96-103. Retrieved from http://lib.geo.ugm.ac.id/ojs/index.php/ jbi/article/view/168

Purwaningsih, Y. (2008). Ketahanan Pangan: Situasi, Permasalahan, Kebijakan, dan Pemberdayaan Masyarakat. Jurnal Ekonomi Pembangunan: Kajian Masalah, 9(1), 1-27. Retrieved from http://journals. ums.ac.id/index.php/JEP/article/view/1028

Purwaningsih, Y., \& Istiqomah, N. (2015). Analisis Dampak Alih Fungsi Lahan terhadap Tingkat Ketahanan Pangan Rumah Tangga Petani di Karanganyar ,. Jurnal Agraris, 2(1), 99-106.

Quasem, M. A. (2011). Conversion of agricultural land to non-agricultural uses in Bangladesh: extent and determinants. Bangladesh Development Studies, 34(1), 59-85. Retrieved from http://search.proquest.com/docview/1272077993?accountid $=13042 \% 5 \mathrm{Cnhttp}$ ://oxfordsfx.hosted. exlibrisgroup.com/oxford?url_ver=Z39.882004\&rft_val_fmt=info:ofi/fmt:kev:mtx:journal\&genre $=$ article\&sid $=$ ProQ:ProQ:ibssshell\&atitle $=$ Conversion + of + agricultur al+land+to+

Supriyadi, A. (2004). Kebijakan Alih Fungsi Lahan dan Proses Konversi Lahan Pertanian (Studi Kasus di Kabupaten Pasuruan, Jawa Timur). Institut Pertanian Bogor. 
Avalaible online at http://journals.ums.ac.id, Permalink/DOI: 10.23917/jep.v19i1.4435

Jurnal Ekonomi Pembangunan: Kajian Masalah Ekonomi dan Pembangunan, 19 (1), 2018, 1-11

Suputra, D. P. A., Ambarwati, G.a.a, I., Tenaya, Tarigan. (2006). Perencanaan Pembangunan \& Narka, I. M. (2012). Faktor-Faktor yang Wilayah. Jakarta: Bumi Aksara. Mempengaruhi Alih Fungsi Lahan Studi Kasus di Subak Daksina, Desa Tibubeneng ,. Agrobisnis Dan Agrowisata, 1(1), 61-68. 